\title{
New and Old Materials in the Architectural Heritage. Case Study: Behaviour of Glass Fiber Reinforced Lime Based Concrete
}

\author{
Ana Almerich-Chulia, Jesica Moreno-Puchalt, Adolfo Alonso-Dura, Veronica Llopis-Pulido \\ Universitat Politècnica de València/Department of Continuum Mechanics and Theory of Structures, Valencia, Spain \\ Email: analchu@mes.upv.es, jemopuc@mes.upv.es, aalonsod@mes.upv.es, vllopis@mes.upv.es
}

\begin{abstract}
In recent years, the importance of structural interventions in architectural heritage for repairing and strengthening has increased considerably. During the 20th century, there has been a tendency to replace traditional materials with the most widespread "new" materials used: steel and reinforced concrete. However, in many cases, the durability of the interventions has not been as expected.

An extensive damage to the ancient masonry due to incompatibility of reinforced concrete with the old materials has been clearly established, leading to a rapid deterioration. International centers, such as ICOMOS, have recommended the use of materials similar in composition and properties to the original ones for the restoration works. An adequate choice of mortars is critical to the success of a restoration process. Compatibility between the new mortar and the original components is very desirable. So that, the renascence of lime based mortars technology for the restoration of historic structures has been observed. Besides that, steel presents several practical difficulties in protecting against corrosion and environmental effects, and sometimes in their handling at the construction site. As an alternative, steel can be replaced with advanced fibre reinforced polymer (FRP) materials, commonly called composites, which offer excellent physical and mechanical properties and are lightweight and insensitive to corrosion.

The present analysis shows the use of lime-based concrete, with pozzolanic loads, internally reinforced by GFRP bars. Lime concrete manages to consolidate the existing historical building, providing safety to masonry structure and solving their structural problems. In addition, GFRP bars exhibit a high tensile strength required. The performance of this combination is investigated by numerical simulation using the FEM method. The response is simulated firstly with current materials (as reference) and finally with the proposed lime based concrete reinforced with GFRP.
\end{abstract}

Index Terms - lime concrete, GFRP bar, structural behavior, restoration, lime mortar

\section{INTRODUCTION}

During the 20th century, a change in the restoration processes of historical buildings has been produced. There has been a tendency to replace traditional materials with more used and widespread "new" materials: steel and reinforced concrete. However, in many cases, the

Manuscript received August 10, 2018; revised April 20, 2019. durability of the interventions has not lasted as expected. A clear and extensive damage has been produced to the ancient masonry due to incompatibility of reinforced concrete with the old materials, leading, so, to a rapid deterioration. The present analysis shows the advantages of the use of hydraulic lime-based concrete, with pozzolanic loads and internally reinforced by GFRP bars in Cultural Heritage works (Fig. 1).

Lime concrete manages to consolidate the existing historical buildings, providing safety to masonry structures and solving their structural problems. It is capable of accommodating movement of the masonry. Moreover, GFRP bars, which have been used in structural restoration for much time, exhibit a high tensile strength. Furthermore, they allow good compatibility with limebased mortar because of they have similar elasticity modulus.
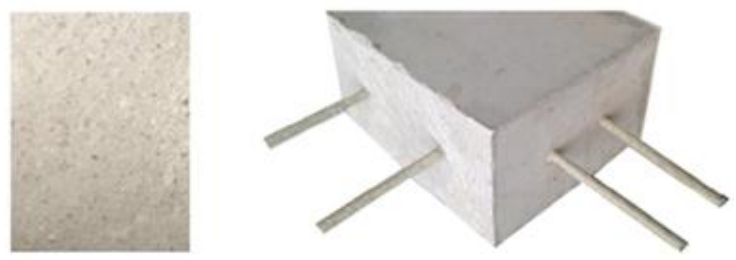

Figure 1. Lime Concrete + GFRP bar.

\section{CASE Study: S. ESTEBAN CHURCH}

\section{A. Architectural Description}

The parish church of San Esteban is one of the oldest in Valencia, being one of the ten consecrated by the first bishop of Valencia reconquered Don Pedro de Albalat. It is built on one of the old mosques of the Muslim city.

The Valencian scholar Gaspar Escolano, who was also rector of the Church of San Esteban in 1597, points out that the church was originally a Roman temple dedicated to Hercules, which later would be Christianized and later mosque.

The primitive Gothic temple was already built in 1276 as a new building, because according to the historical documentation of the Archive of the Cathedral of Valencia for this date there was no Christian temple with the appearance of a mosque except the church of Santo 
Tomás. It was a temple of a single nave with wooden cover and diaphragm arches [1].

On January 26th 1472, the first stone of what will be the temple in its current appearance was placed. The works in the building lasted until the sixteenth century. Due to problems of stability, new works were capitulated at the beginning of the 16th century. In 1514 because of the dilapidated state that presented the temple, the parishioners decided to rebuild it, demolishing the first arcade next to the presbytery and building it again from its foundations. Moreover, in 1515 the capitulation was signed with the stonecutter Fernando de León for the reconstruction of the two following sections. Fernando de León must follow the model already concluded "with a single nave and side chapels"[2].

The temple was configured with a single nave of seven sections with side chapels between buttresses and polygonal presbytery, following the model of most of the city's parishes.

At the beginning of the seventeenth century, it presents problems again in the masonry, so it is decided to rebuild the church performed practically as it has come. (Fig. 2)

At patrimonial level, the Parochial Church of San Esteban reaches the category of Cultural Interest Property after the declaration like artistic historical monument by Decree of 14 of September of 1956 (BOE N² 287/ 13-101956). [3]

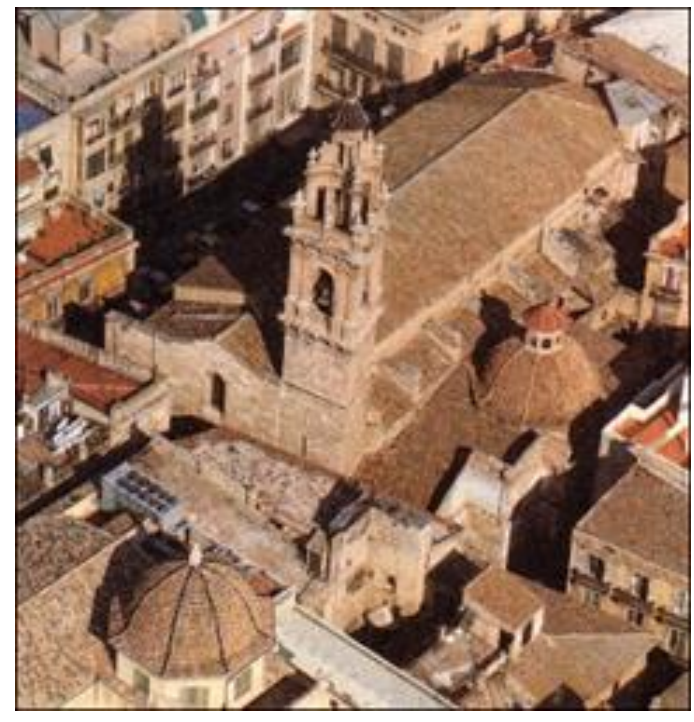

Figure 2. St. Esteban Church.

In the current spatial configuration of the ensemble: church, sacristy, communion chapel and tower, we find elements from the construction phase corresponding to the rebuilding of the church of the early seventeenth century. And the transformations of its distribution of space and the interior decoration of Baroque and Neoclassical origin, coming from the late 17th century as well as the 18th and 19th century.

The plan of the church is a single rectangular nave of seven sections, approximately $12.60 \mathrm{~m}$ x $33 \mathrm{~m}$, with side chapels between buttresses, six on the side of the epistle and seven on the side of the gospel. (Fig. 3)
All the sections or spans of the nave, including the last one, which is looking out over the imafronte, are covered with a ribbed structure and partitioning vaults with a keystone. In the interior of the nave, the average height up to the transverse arch is $16.80 \mathrm{~m}$ and up to the stone cornice is $10.45 \mathrm{~m}$. The apse is semi-circular, preceded by a straight section that separates it from the central nave, and covered by a circular vault and section of a barrel vault. In the back of the apse, the polygonal perimeter and the abutments of its previous configuration are hidden by its current circular configuration.

The main entrance is behind the fourth chapel from the apse, on the side of the Gospel.

The bell tower is in the south-west corner of the Church. It presents a square plant with sides approximately of $4.75 \mathrm{~m}$ long, and reaches a height of $41.69 \mathrm{~m}$. In height, it is composed of a first ashlar masonry up to $22.76 \mathrm{~m}$ that matches with what could be the original volume of the tower. The rest up to its total height is made with solid brick factory by three bodies superimposed and divided by ornamental elements of friezes with corbels and cornices, topped by a lantern covered by a dome, which is also covered by a roof of glazed tile and weather vane. This last brick body comes from the extension of the 18th century and it is the current bell tower.

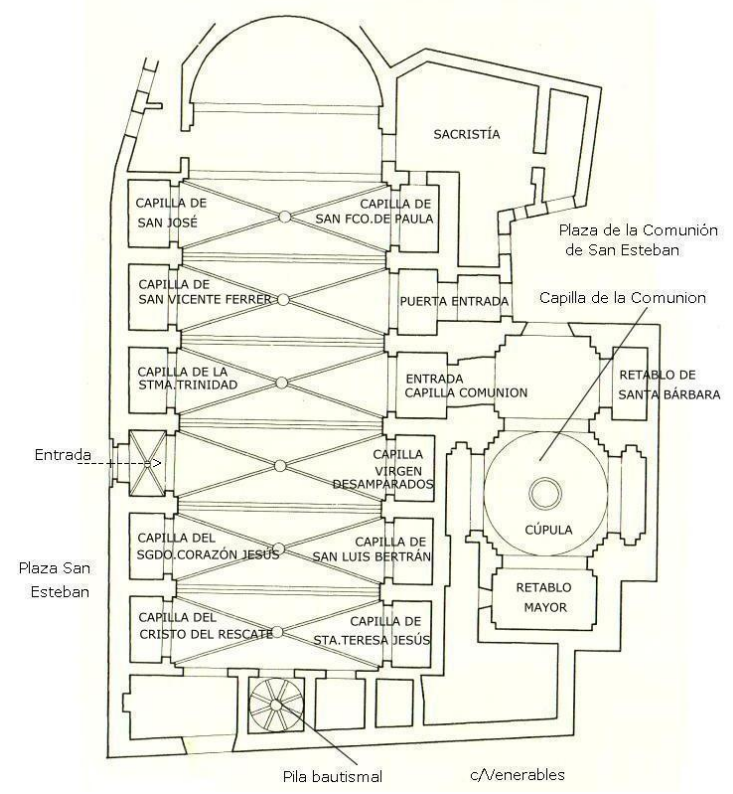

Figure 3. Plan view of the church.

On the outside of the building, the roof of the church located on the vaults that enclose the space inside, is composed in the central nave by two sloping slopes towards the north and south façade. In the apse, it is formed by a first span covered as the nave and four spans with a monopitch roofs crossing the polygon that formed the apse in the previous construction phase. In the section of nave located at the entrance of the church the elements that formed the cover of the early s. XVII. The rest of the sections of the nave and the apse come from a transformation of the roof belonging to the mid-twentieth century that although disposed as a gabled roof is 
elevated above the level of the previous one. The cover of the lateral chapels is a water with a slope to the north and south elevations in each case. The roofs are finished with cornice or eaves built with ceramic pieces of brick.

The facades show their constructive nudity, highlighting their smooth walls with hardly any gaps and the important buttresses. They emphasize in them only ornamented covers realized in stone.

In the north elevation, we can distinguish three levels of composition. The lower level of the masonry that contains the walls and roofs of the side chapels and the front door to the Plaza de San Esteban. The upper level of masonry and ashlar masonry made up of the facing of the nave. The third level configured with the roof in which the conservation of the roof of the XVII century can be seen in the section located at the foot and in the rest the overhang of it in the middle of the XX century.

The west elevation, made with ashlar masonry, is distinguished by two stonework doors on the lower level, the central window with medieval traces that occupy the upper central part of the wall and the presence of the tower.

Regarding the tower, it stands out in its facades the first body of ashlar masonry that shows a great sobriety, without any type of ornament until its cornice, with the exception of two small windows overlooking to the west elevation.

The south elevation is composed of the façade of the communion chapel and the section that contains the entrance to the church and the facade of the sacristy. This last section comes from an intervention of the late nineteenth century with academic features. Part of the facade and cornice of the chapel of the communion is hidden with this intervention, by means of a parapet that tries to equal the heights of finishes eaves and cornices.

On this façade, without facing directly into the public space while remaining in a later plane, the walls of the nave, the apse and the buttresses can be seen. This elevation was quite altered from the communion chapel construction that involves the modification of the height of the roofs of the side chapels and that of the buttresses, on this side of the Church [3].

\section{B. Constructive Description}

There are no known data on the foundations of the church, as there are no inspections carried out and documented in the building, but it should be noted that deformities are not observed that allow the deduction of seats from the walls or pillars.

The following elements are differentiated in the supporting structure of the building:

- Buttresses: Elements that belong to the vertical supporting structure, with an average section of $3.50 \times 0.70 \mathrm{~m}$ and different heights.

- Supporting structure of roof: composed by the traverse arches with $12.60 \mathrm{~m}$ of light, the shaping arches of variable lights on the $4.00 \mathrm{~m}$., And the elements of the 'transept that conform the cover. It is in all cases made of stone elements.

- Walls: The walls of the facades, the main one, the imafronte and those that close the apse's head, are made of ashlar masonry. The width of the walls is approximately $1.00 \mathrm{~m}, 0.94 \mathrm{~m}, 0.38 \mathrm{~m}$ respectively.

- Vaults: The roof of all the sections of the central nave is formed by ribbed vaults with a keystone. In the apse, the vault is circular with a stretch of barrel vault, in separation with the nave. All the vaults are made of ceramic plementry of two threads resting on nerves of stone that form the shaping arches and the tiercerons.

- Roof: The roof system of the temple is solved by curved ceramic tile in all cases. There is a gabled roof in the central nave and a saddle roof in the apse and, in a lower level is the slope that covers the lateral chapels. In the last section of the central nave, the one located behind the imafronte, the roof that comes from the construction phase of the early seventeenth century is maintained. However, the roof of the apse and that of the six sections that cover the nave is the result of the transformation of the roof that previously existed in this area. In the twentieth century around the 50's, the over-elevation of this cover was made. This transformation implied an increase in the height of the ridge at $1.46 \mathrm{~m}$. and a modification of the slope. To support the structural elements that make up the base and closing the entire space, creating a new horizontal support plane located at $1.42 \mathrm{~m}$ above the previous one [3].

\section{STRUCTURAL MODEL}

This research is performed using numerical simulations through the finite element method (FEM). The use of the finite element structural analysis of large ancient buildings has two important advantages: firstly, the ability to generate detailed and complicated geometric models, being even possible to model cracks by establishing a discontinuity between elements; and secondly, the ability to simulate a variety of loads, thanks to take into account the compatibility of movements.

San Esteban Church's is one of the oldest church in Valencia (Spain), a historical building which belongs to Spanish Cultural Heritage. Esteve's project provides all the graphic information necessary of the state of this church in 2008, prior to official works executed. The loads that affect the Church have been evaluated. Being such a massive building, the variable loads of use and snow are almost insignificant compared to the permanent ones of own weight, reason why they have been despised. In the same way, due to the location of the Church in the historical center of the city, surrounded by buildings, the variable action of the wind has also been disregarded.

The 3D model has been carried out from this graphic studio, with the support of the tools "BOVEDAS 3D" and "ANGLE" [4], which are subroutines lisp for CAD (Fig.4). The geometry and structure of the church is simulated with them: walls, vaults, domes and cover, assigning the mechanical characteristics of their materials, and the loads that act. (Fig 5)

The 3D church model consists of solid elements, shells and frames. The high number of elements in the complete model makes impossible to run the analysis, so it is necessary to use a reduced model, a model of the 3 central spans of the church (Fig. 6). 


\section{STRUCTURAL INTEGRITY}

The numerical simulation of structural integrity is made through the software "ANGLE" [4] based on the mentioned reduced model of three central spans, obtaining stresses, deformations and breakage points of the church. The first analysis focuses on the structural response to gravity loads, through a linear static analysis [5].

The vertical displacements obtained in this linear analysis are smaller than $1 \mathrm{~mm}$, as corresponds to a structure of great rigidity. In the stress analysis, the maximum values of strength are not reached for each of the materials that constitute the structure of the church. (Fig. 7)

If we go on to evaluate the tensions that develop both in the solid elements and in the shell elements, that is, in the walls and vaults respectively, it can be observed that in none of the three axes, the maximum values for each material that make up the structure of the church are reached. (Fig. 8, Fig. 9)

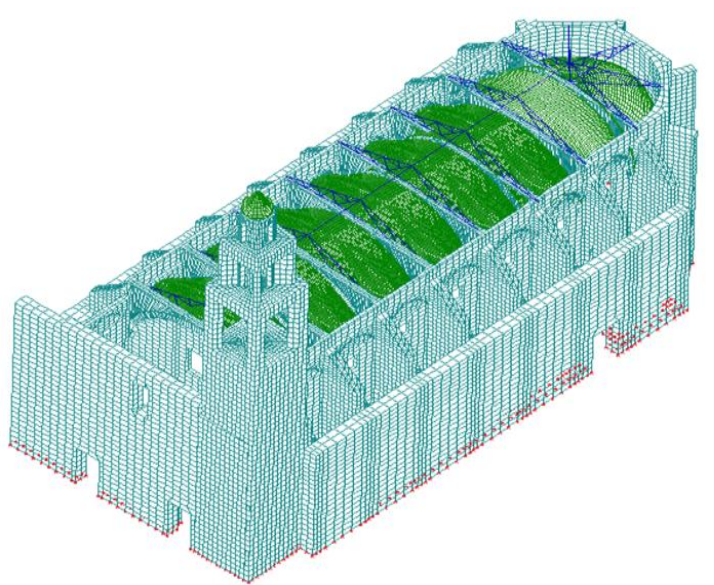

Figure 4. 3D model.

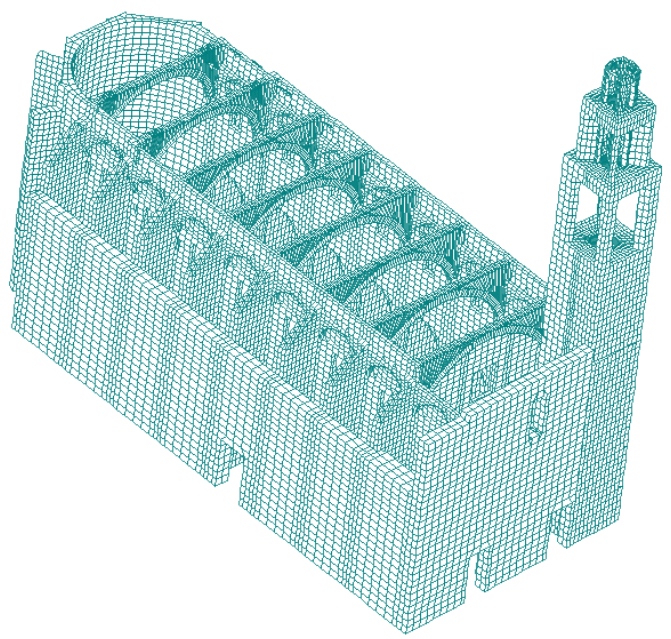

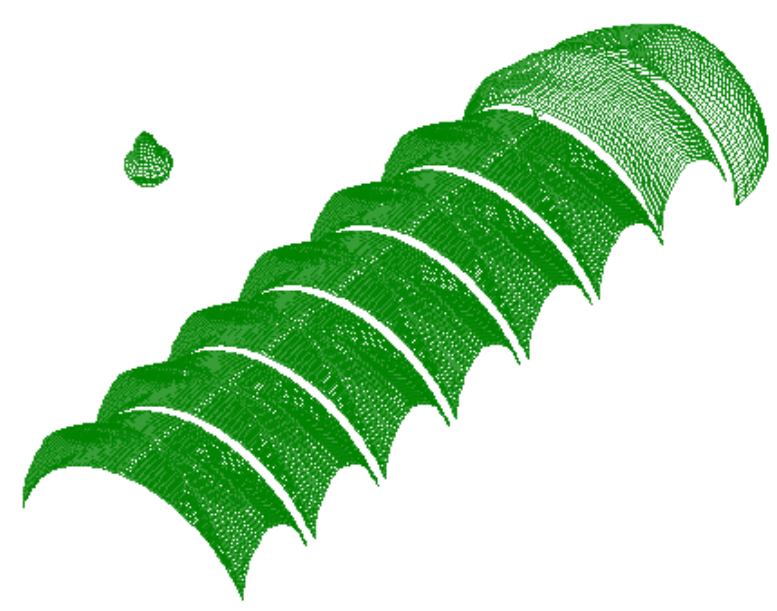

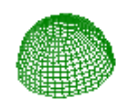

Figure 5. 3D model.

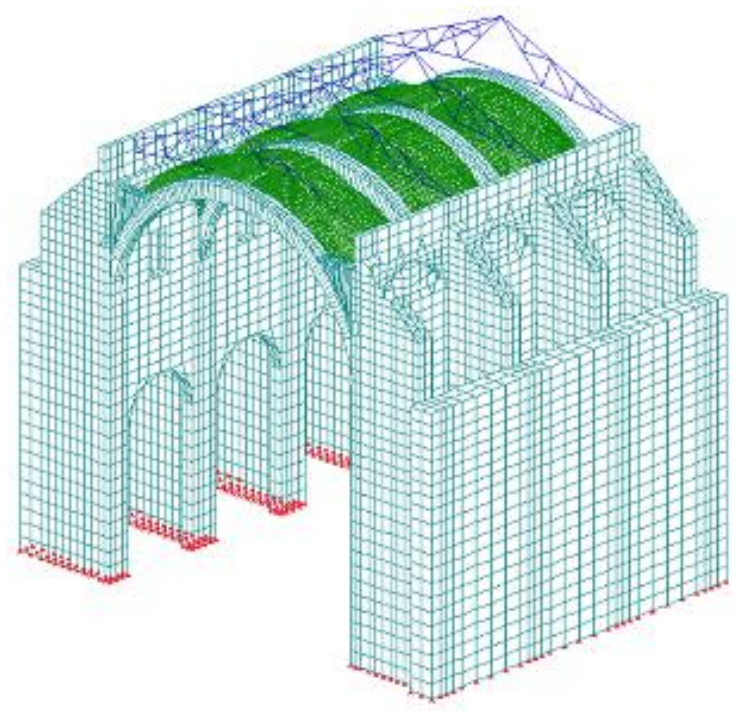

Figure 6. 3D Structural model of 3 central spans.

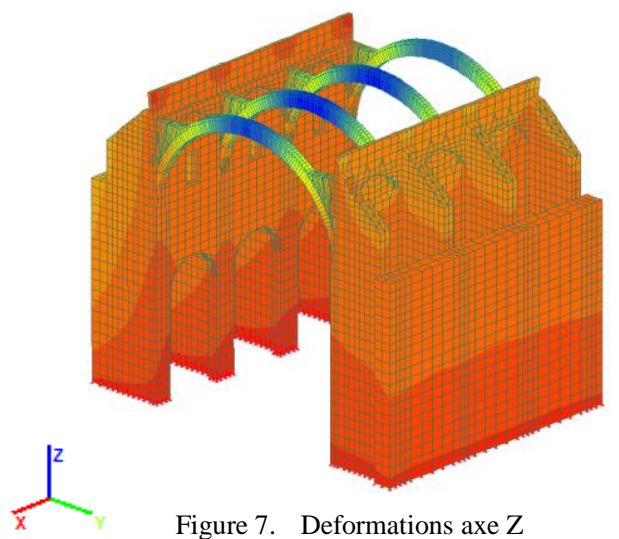

Figure 7. Deformations axe Z 


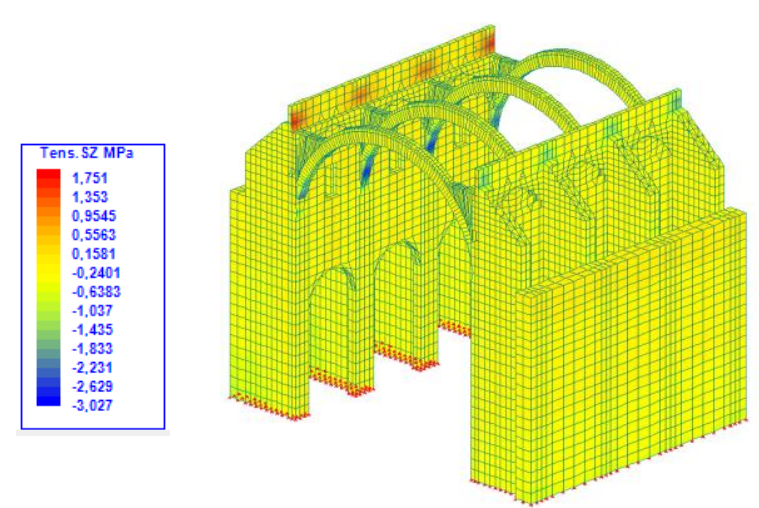

Figure 8. Solid Stresses Sz

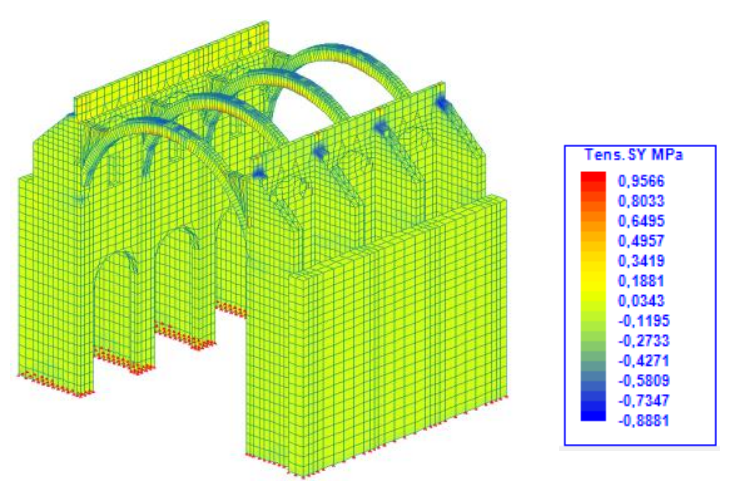

Figure 9. Solid Stresses Sy

The non-linear static study, the pushover analysis, is modelled with 10 loading steps, increasing the load by $10 \%$ at each step (Fig. 10, Fig. 11, Fig. 12). The structure weakens at the points where the roof beams are supported, with a damage index (capacity/demand ratio) equal to or greater than 1 in the initial loading steps, deforming and collapsing at $80 \%$ of the load (Fig. 13). The index $d$ indicates the degree of deterioration of the material $(0 \leq \mathrm{d}$ $\leq 1$ ), being the value 0 the non-damaged state and 1 the total deterioration of the resistant area. When the wall is broken, the other elements fulfill their structural purpose.

\section{Structural Restoration Project}

At the beginning of the 20th century, a change in the structural conception of historic buildings began to take place, especially as a consequence of the way in which they were intervened. It was then when the generalized practice of replacing traditional materials with a new material in those times began the reinforced concrete.

Unfortunately, the durability of these interventions with reinforced concrete has not been as expected, leading to a rapid process of deterioration in many of them. It is from the eighties, when they begin to appear different positions at the time of restoring the historical heritage, which leads to the appearance of various alternatives for the same problem.

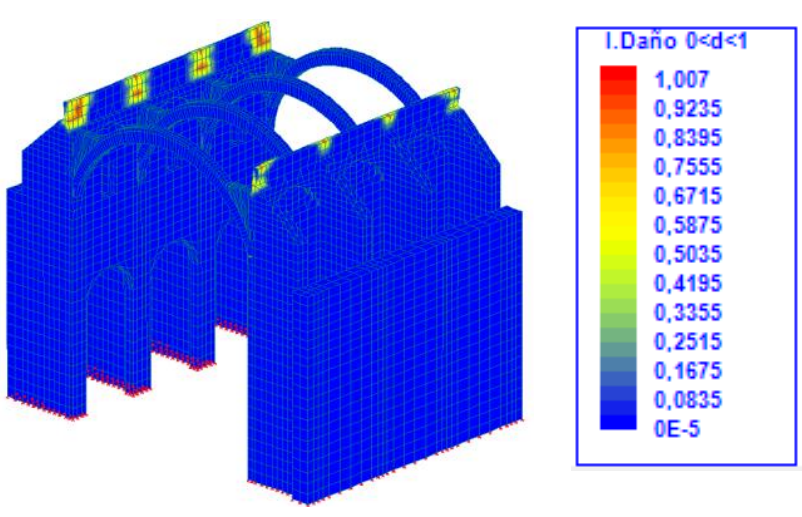

Figure 10. Damage index at 30 of the load

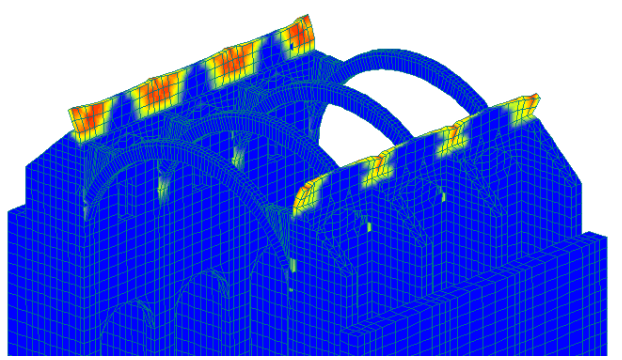

Figure 11. Damage index at 50 of the load

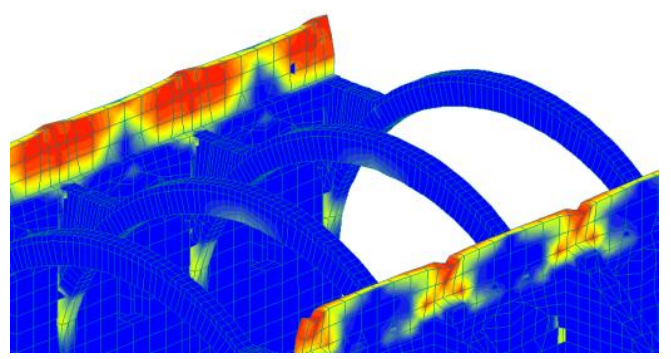

Figure 12. Damage index at $70 \%$ of the load

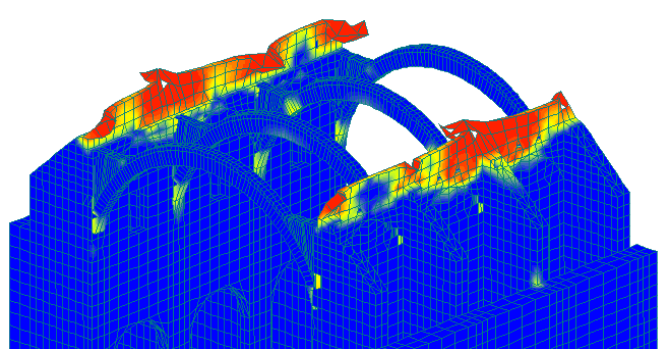

Figure 13. Damage index at $80 \%$ of the load

However, the restoration with reinforced concrete has a doubtful durability for the possible harmful effects more than beneficial, since the concrete experiences with time a deterioration by external agents much more accentuated than the traditional materials, being able to attack the stability of the wall which is intended to be repaired [6].

Therefore, a large number of specialists in the refurbishment began to discourage the use of reinforced concrete for the constant problems it was generating, in addition to considering that this technique was not as durable, compatible or reversible with the old buildings.

Since the end of the 20th century, alternatives for the restoration, repairing and protection of structures 
subjected to deterioration caused by years of exposure to the elements as well as natural aging of materials have been investigated and developed. These products are designed for the realization of a correct and lasting restoration and rehabilitation of monuments and old buildings.

Therefore, the use of compatible materials based on the previous study of traditional materials becomes an essential requirement in all restoration. Traditional materials (such as lime and sand mortars) have already shown their compatibility with historical materials (mortars, stones, masonry, wood). In this regard, Liu et al. [7] have shown that traditional materials not only have a good compatibility, but also reduce the deterioration of the mechanical characteristics of historical materials over time. The lime or plaster concretes are able to structurally consolidate the existing buildings, giving security to the brick and stone constructions, solving their structural problems.

In addition, it is necessary not to increase the weight of the structure. This has led architects and engineers to use a wide variety of repair or reinforcement techniques to improve the structural response of historical structures based on what it has been called new materials. Their resistance, lightness and excellent behaviour against climatic agents and corrosion, make them excellent candidates for their use in restoration projects. Among these new materials include fibers, whether carbon, glass or aramid, in its many commercial presentations.

The intervention proposal is designed according to the results of this structural analysis, which has two main objectives:

1. Strengthen the structural behaviour of the wall where the roof supports. A beam is proposed overall perimeter of the nave and over the traverse diaphragm arches to the nave. Thus, the wall is structurally consolidated. To do this, the diaphragm arches must reach the height of the keystone. In this way, the beam also passes over the diaphragm arches, reforting in the transverse direction.

2. Use noble materials according to historical constructions, as well as innovative materials developed in the last decades. International centers, such as ICOMOS or ICCROM, have recommended the use of materials similar in composition and properties to the original ones for the restoration works.

Therefore, it is proposed to make the beam with a lime concrete with pozzolanic charges, internally reinforced fiberglass reinforced polymer rods. (Fig. 14, Fig. 15).

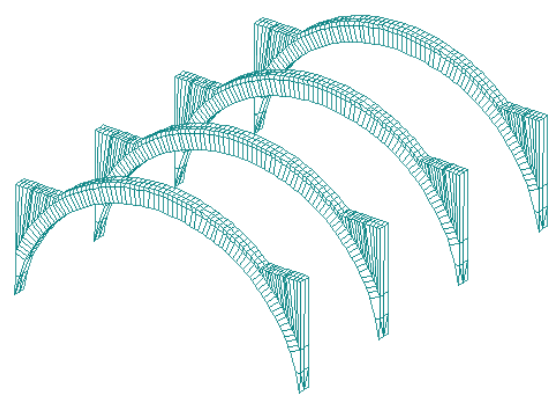

Figure 14. Initial model
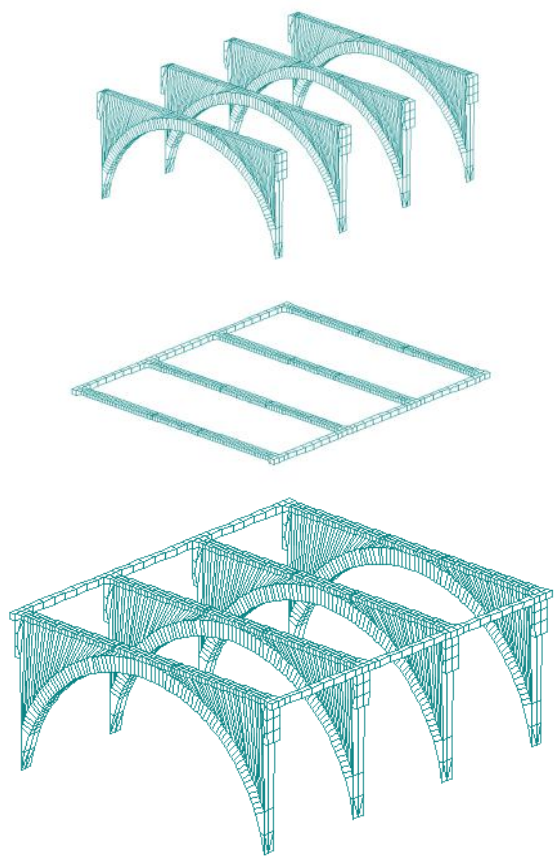

Figure 15. Solution model

Fig. 16a shows the selected lime concrete in the intervention proposal, which its viability is analyzed. Table I shows its mechanical characteristics [8], [9], [10], [11]:

TABLE I. MEChaniCAl CHARACTERISTICS OF LiME CONCRETE

\begin{tabular}{|c|c|}
\hline Elasticity Modulus E $(\mathrm{GPa})$ & $10-20$ \\
\hline Compression strength fc(MPa) & $5-20$ \\
\hline Density $\rho\left(\mathrm{kg} / \mathrm{m}^{3}\right)$ & 1.600 \\
\hline
\end{tabular}

In the same way, Table II shows the mechanical characteristics presented by the glass fiber bars (Fig. 16b) [12], [13].

TABLE II. MECHANICAL CHARACTERISTICS OF GFRP BAR WITH 95\% PROBABILITY

\begin{tabular}{|c|c|}
\hline Tensile strength ft $(\mathrm{MPa})$ & $635-915$ \\
\hline Elasticity Modulus E $(\mathrm{GPa})$ & $34,1-41,9$ \\
\hline Compression strength fc $(\mathrm{MPa})$ & $290-425$ \\
\hline Elongation $(\%)$ & $1,3-3$ \\
\hline Módulo de Poisson & 0,30 \\
\hline
\end{tabular}
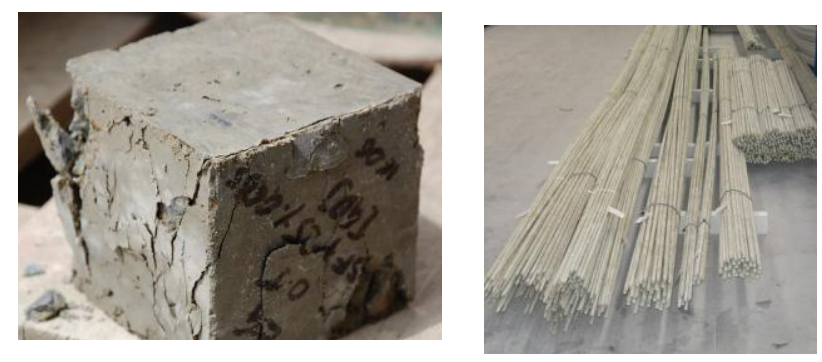

Figure 16. a: Lime Concrete - b: GFRP bars 
The characteristics of the combined material "lime concrete + GFRP bar" (Table III) are assigned to this beam in the model.

TABLE III. MECHANICAL CHARACTERISTICS OF MATERIALS

\begin{tabular}{|c|c|c|c|c|}
\hline & $\rho\left(\mathrm{kg} / \mathrm{cm}^{3}\right)$ & $\mathrm{E}(\mathrm{GPa})$ & $\mathrm{fc}(\mathrm{MPa})$ & $\mathrm{ft}(\mathrm{MPa})$ \\
\hline Lime concrete & 1.600 & $10-20$ & $7-14$ & -- \\
\hline $\begin{array}{c}\text { GFRP(nucleo) } \\
\text { Limeconcrete } \\
+ \text { GFRP }\end{array}$ & 1.980 & 40 & 340 & 600 \\
\hline
\end{tabular}

When analysing the numerical simulation of structural integrity of lime concrete reinforced by GFRP, the maximum values of strength in each of the existing materials are not reached. (Fig. 17)

Focusing on the study on the created band, the maximum stresses, both tension and compression, are obtained in order to serve as calculation values for the dimensioning of the reinforcing beam. (Fig. 18)
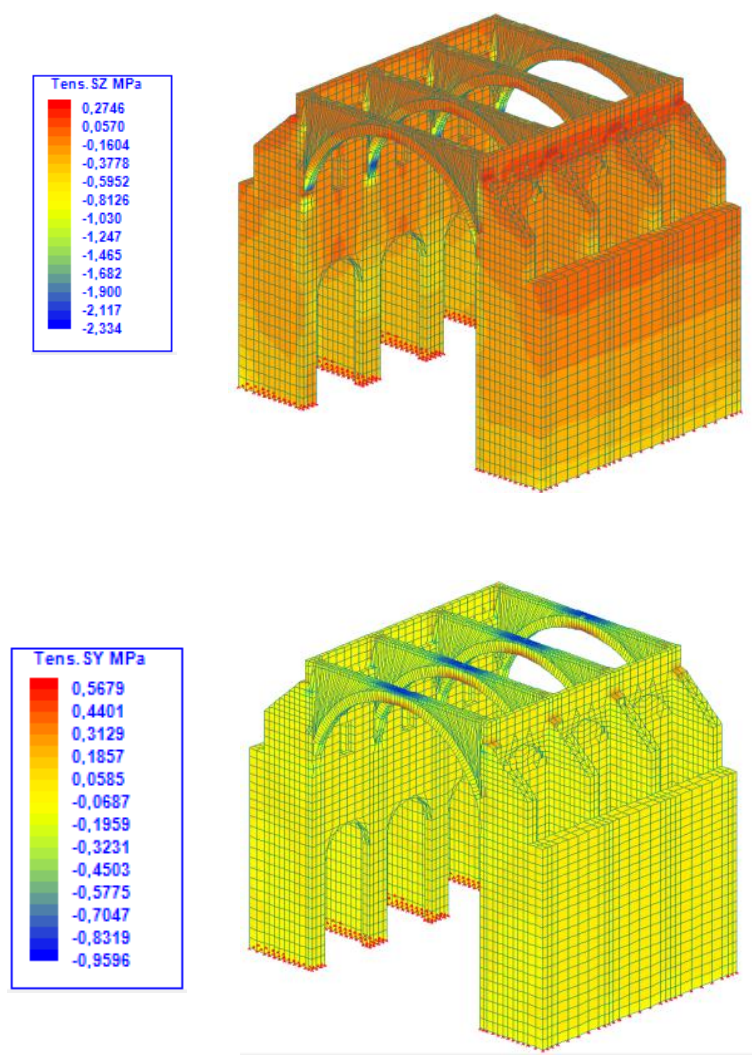

Figure 17. Solid Stresses structural solution

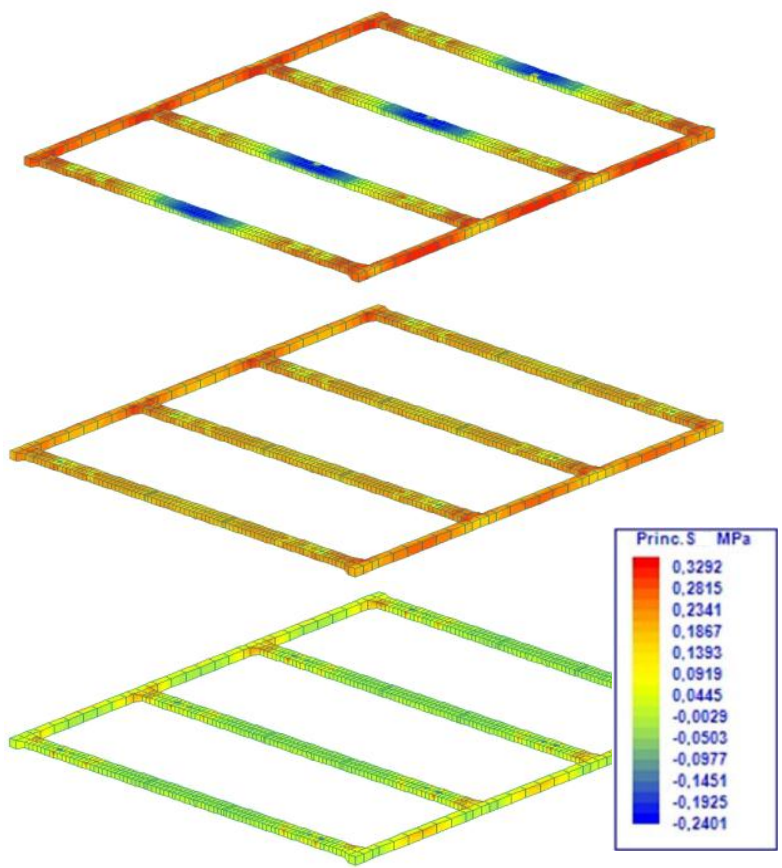

Figure 18. Principal Stresses (I, II, III) in proposal beam

Finally, a static non-linear analysis of the complete structure with the proposed intervention is carried out (Fig. 19), obtaining the stress distribution, deformations and the damage factor in the structural elements. All of them are less than the ultimate values of the materials [5].

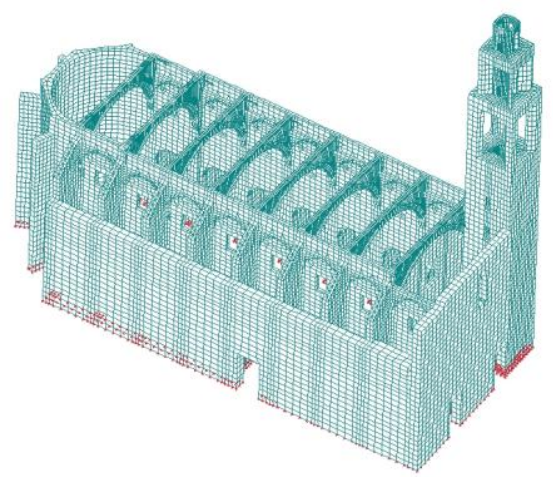

Figure 19. Final structural solution model

\section{CONCLUSIONS.}

The knowledge of the mechanical behaviour of the materials what allows us to be able to arrive to decide if they are valid or not for the purpose with which it is tried to use them.

We have two materials, lime concrete and fiberglass reinforced polymer, which are combined to give a possible solution to the structural problems that have arisen, either by the use of concrete in masonry structures, stone, or by the deterioration of these with the passage of time.

After the results obtained, we can say that the lime concrete reinforced with GFRP is a viable alternative to 
replace the traditional reinforced concrete for a structural refurbishment in ancient buildings.

\section{REFERENCES}

[1] Diez Arnal, J (online)

http://www.jdiezarnal.com/valenciaiglesiadesanesteban.html

[2] Gómez-Ferrer, M. "Iglesia parroquial de San Esteban de Valencia" in Monumentos de la Comunidad Valenciana, ch. X, Spain. Generalitat Valenciana, 1995.

[3] Esteve Sebastia, N. "Proyecto básico y de ejecución Intervención y Restauración Iglesia Parroquial de San Esteban, Valencia" in Fundació "La Llum de les Imatges". Spain. Generalitat Valenciana, 2008.

[4] Alonso Durá, A. "ANGLE. Structural Analysis Software for Finite Elements". Software, 2014. Development in Department of Continuum Mechanics and Theory of Structures, Universitat Politècnica de Valencia, Spain.

[5] Almerich Chulia, AI. "Análisis estructural de la Iglesia de San Esteban de Valencia. Propuesta de intervención mediante la utilización de redondos de fibra de vidrio". MS thesis, Universitat Politècnica de València, Spain, 2015 http://hdl.handle.net/10251/58200

[6] Garate Rojas, I. "Artes de la cal". Ministerio de Cultura. Instituto de Conservación y Restauración de Bienes Culturales, 1994.

[7] Liu, Q.; Liu, Y,; Zeng, K.; Yang, F.; Zhu, H.; Y Liu Q. "Advanced design of Chinese traditional materials for the conservation of historic buildings", Journal of Archaeological Science, 2011. DOI:10.1016/j.jas.2011.03.036

[8] Grist, E. "The implementation of innovative and sustainable construction materials". Thesis, Department of Architecture and Engineering. University of Bath. England, 2014

[9] Grist, E.; Paine, K.A.; Heath, A.; Norman, J.; Pinder, H. "Limepozzolan concretes: addressing project-specific questions". Construction Building Materials, 2013.

[10] Grist, E.; Paine, K.A.; Heath, A.; Norman, J.; Pinder, H. "Structural and durability properties of hydraulic lime-pozzolan concretes". Cement and Concrete Composites, vol: 62 pp: 212223, 2013.

[11] Velosa, A.L.; Cachim, Pb. "Hydraulic-lime based concrete: Strength development using a pozzolanic addition and different curing conditions. Construction and Building Materials". $\mathrm{N}^{\circ} 23$ (5), pp. 2107-11, 2009.

[12] Almerich Chulia, A.I. "Diseño, según Estados Límites, de estructuras de hormigón armado con redondos de fibra de vidrio GFRP”. Thesis, Universitat Politècnica de València, Spain, 2011.

[13] Arteaga, A.; López, C. "Informe no 19.596-I. Ensayos de tracción compresión y adherencia de redondos de materiales compuestos para su uso en hormigón". Instituto de ciencias de la Construcción "Eduardo Torroja” (IETcc), Madrid, España. 2009.

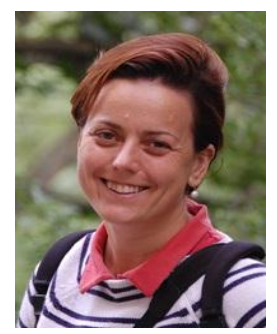

Ana Isabel Almerich Chulia was born in Valencia, Spain in 1973. She is an Industrial Engineer by Universitat Politècnica de València (UPV). In 2011, she earned her doctorate in structural engineering from this University. She has a Master in Science too, in Architectural Heritage Conservation, earned in 2015 at UPV.

She began her teaching activity in 2001 as Assistant Professor, and since 2006 she holds Associate Professor status in the Department of Continuum Mechanics and Theory of Structures at Universitat Politècnica de València. Moreover, she is the 1st assistant head of this Department since 2008.

She focuses her research interests on issues of project structural analysis, reinforced concrete, composites, finite element modelling, innovative materials. She has published papers on these issues, with international peer-reviewed process.
Dr. Almerich-Chulia is a member of Academic Exchange Information Centre (AEIC) and Honk Kong Chemical, Biological \& Environmental Engineering Society (CBEES)

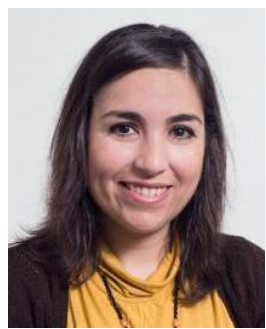

Jésica Moreno Puchalt was born in Valencia (Spain) in 1979. B.Arch. Universitat Politècnica de València (UPV), Spain (2004). She obtained her Official Master title in Conservation of the Architectural Heritage in 2011 and that of Doctor in Architecture in 2016.

Her professional career contemplates not only new builds and renovation but also public and private promotion. She begins her educational activity in 2009 as a part-time professor in the Department of Continuum Mechanics and Theory of Structures at UPV in Valencia, in which she continues at present. She teaches in the Master in refurbishment of buildings and urban regeneration as well as in the Master in construction of virtual parametric building models, both in the UPV.

Some of her main papers published are: "Seismic evaluation of the Santa Catalina's church of Valencia applying a scalar damage model" (Bologna, Mechanics of Masonry Structures Strengthened with Composite Materials, 2017), "Structural behavior analysis of the bell tower of Santa Catalina's church of Valencia" (México, $9^{\text {th }}$ International Conference on Structural Analysis of Historical Constructions, 2014), "Analysis and rehabilitation of San Miguel Arcángel church in Jalance in Valencia" (Porto, $3^{\text {rd }}$ International Conference on Heritage and Sustainable development, 2012)

Dr. Moreno is a member of Colegio Territorial de Arquitectos de Valencia (CTAV). She won a European Union Prize for Cultural Heritage, Europa Nostra Award 2012 (Europa Nostra Award for the Restoration study for the Nolla Palace, Meliana (Spain) as a member of the technical team of Arae Patrimonio SLP

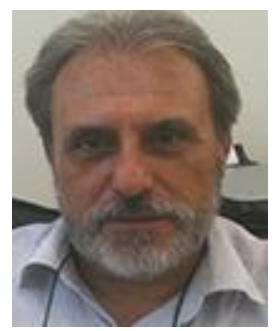

Adolfo Alonso Durá He obtained his Docto in Architecture in 2000. Professor of structures in the Department of Continuum Mechanics and Theory of Structures at Polytechnic University of Valencia in Valencia. Vice President of APYCE, Association of designers and structure consultants. Member of Architectural Heritage Restoration Institute in 2001

He has developed a structural analysis software for finite elements, called ANGLE. Research activity in the group of Analysis of Intervention in Historic Monumental Architecture. In this field, he has made scientific publications, included in specific databases in the field of Architecture and Engineering, including at international level, with a peer-review process.

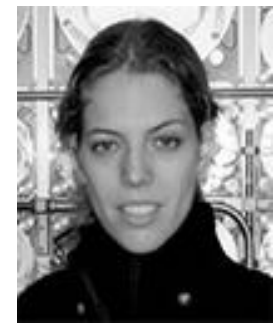

Verónica Llopis Pulido She obtained her Doctor in Architecture from the School of Architecture of Valencia in 2014, specialization in Building, Universitat Politecnica de Valencia (UPV).

Part-time professor in the Department of Mechanics of Continuous Media and Theory of Structures at UPV. Member of the Coordinating Team of the Degree: University Specialist in Building Rehabilitation.

Official Master in Conservation of the Architectural Heritage in 2007. Member of the Architectural Heritage Restoration Institute. Research activity in the group of Analysis of Intervention in Historic Monumental Architecture.

In this field, she has made scientific publications, included in specific databases in the field of Architecture and Engineering, including at international level, with a peer-review process. 